\title{
Focus on lens connexins
}

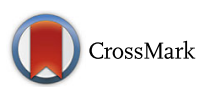

\author{
Viviana M. Berthoud ${ }^{1 *}$ and Anaclet Ngezahayo ${ }^{2^{*}}$ \\ From International Gap Junction Conference 2015 \\ Valparaiso, Chile. 28 March - 2 April 2015
}

\begin{abstract}
The lens is an avascular organ composed of an anterior epithelial cell layer and fiber cells that form the bulk of the organ. The lens expresses connexin43 (Cx43), connexin46 (Cx46) and connexin50 (Cx50). Epithelial Cx50 has critical roles in cell proliferation and differentiation, likely involving growth factor-dependent signaling pathways. Both Cx46 and Cx50 are crucial for lens transparency; mutations in their genes have been linked to congenital and age-related cataracts. Congenital cataract-associated connexin mutants can affect protein trafficking, stability and/or function, and the functional effects may differ between gap junction channels and hemichannels. Dominantly inherited cataracts may result from effects of the connexin mutant on its wild type isotype, the other co-expressed wild type connexin and/or its interaction with other cellular components.
\end{abstract}

\section{Background}

Several years ago, it was hypothesized that gap junctions play an important role in the lens [1]. This was later corroborated by the presence of cataracts in mice with targeted deletion of the lens fiber cell connexins, Cx46 and $\mathrm{Cx} 50$, and by the linkage of cataracts to mutations in the genes encoding these connexins in humans and rodents (summarized in http://cat-map.wustl.edu/; [2]). In this review, we describe connexin channel functions in the lens and we summarize the effects induced by modification/mutation of lens fiber connexins (including alterations of other lens proteins). Channel-independent functions of lens connexins have been previously reviewed [3] and will not be considered here.

\section{The ocular lens}

The eye lens is an avascular and transparent organ, which is responsible for focusing light onto the retina. The lens is composed of two cell types: a monolayer of epithelial cells which covers the anterior surface, and fiber cells which form the bulk of the organ (Fig. 1). Epithelial cells at the equatorial region differentiate into fiber cells through a complex process characterized by cell elongation and elimination of all cellular organelles

\footnotetext{
* Correspondence: vberthou@peds.bsd.uchicago.edu; ngezahayo@biophysik.uni-hannover.de

${ }^{1}$ Department of Pediatrics, University of Chicago, Chicago, IL, USA

${ }^{2}$ Institute of Biophysics, Leibniz University Hannover, Hannover, Germany
}

including the nuclei. Differentiation continues to occur throughout the lifespan of the organism with newly formed fiber cells migrating over and along previous generations of fiber cells. The loss of organelles and the tight packing of the lens fiber cells contributes to minimizing light scattering [4].

\section{Lens connexins}

The ocular lens expresses Cx43, Cx46 and Cx50 (Fig. 1). $\mathrm{Cx} 43$ and $\mathrm{Cx} 50$ are the predominant connexins expressed by epithelial cells, but these cells also express some Cx46 (mostly intracellular) [5-7]. During differentiation, expression of $\mathrm{Cx} 43$ is downregulated while $\mathrm{Cx} 46$ becomes highly expressed. Mature fiber cells express Cx46 and Cx50 [8, 9]. Transcripts for a fourth lens connexin, Cx23, have been identified in zebrafish embryo and mouse lenses [10-12]. In mouse lens fiber cells, the abundance of $\mathrm{Cx} 23$ protein is similar to Cx46, but lower than Cx50 [13]; however, Cx23 knockout mice have transparent lenses [14]. In the human lens, expression of Cx23 has not been reported, and it has been suggested that the $\mathrm{Cx} 23$ gene is inactivated in primates [12]. Because there is doubt about the expression of Cx23 in the human lens, we will not consider this connexin further. 

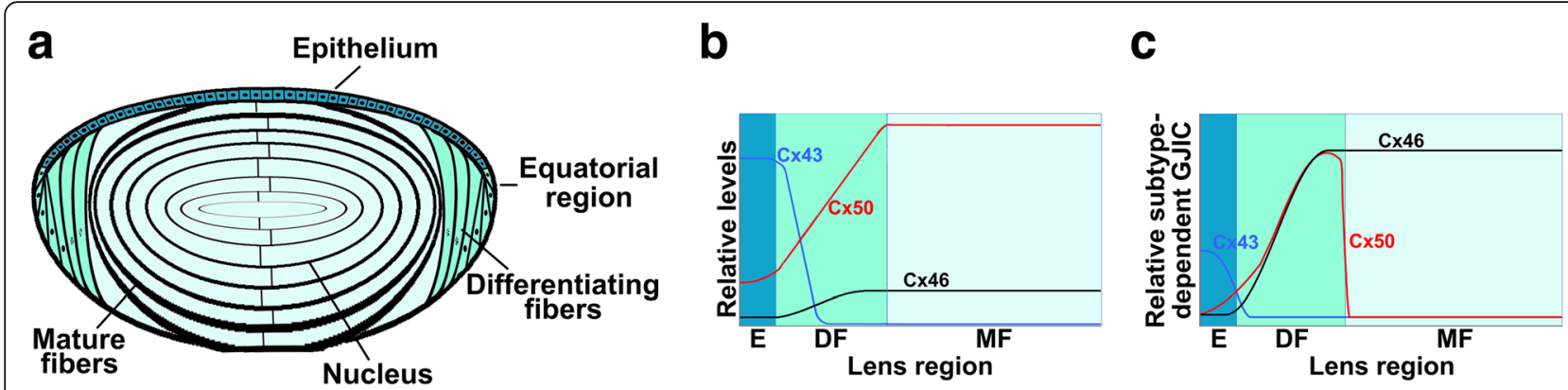

Fig. 1 Distribution, levels and contribution of lens connexins to gap junction coupling. a. Diagram showing the distribution of connexin subtypes in the different regions of the lens. b. Diagram showing the relative amounts of $C \times 43, C \times 46$ and $C \times 50$ in the different lens regions of the adult mouse lens. The relative values of $\mathrm{C} \times 43$ and $\mathrm{Cx} 50$ in the epithelium are based on the quinine-sensitive component of intercellular communication between mouse lens epithelial cells [111]. The relative values of Cx46 and Cx50 in mature fibers are based on analysis of the membrane proteome of the mouse lens fiber cell [13]. The relative amounts on differentiating fibers cells have been drawn partially based on the up-regulation of Cx46 and downregulation of Cx43 expressions between epithelial and mature fiber cells, and the increase in Cx50 between epithelial and fiber cells as detected by immunofluorescence. $\mathbf{c}$. Diagram showing the relative contributions of the different connexin subtypes to gap junction intercellular coupling in cells from the different regions of the adult mouse lens. The curves summarize the data from knockout and knock-in mouse experiments [111-114]. The lens regions have been labeled E, epithelium; DF, differentiating fibers; MF, mature fibers. It is interesting to note that the contribution of Cx46 and Cx50 to gap junction coupling in fiber cells does not correlate with their protein levels

\section{Functions and mechanisms supporting shared and differential roles of lens connexins Shared roles}

Both Cx46 and Cx50 are important for lens transparency. It is believed that the absence of either Cx46 or Cx50 alters the internal circulation system on which the avascular lens relies to maintain metabolic homeostasis. In this system, ions enter the lens at both poles along the extracellular spaces; their electrochemical gradients drive them to enter fiber cells; then, they flow back to the lens surface through gap junction channels and exit at the equator (reviewed in $[15,16]$ ). According to this model, lens fiber gap junction channels facilitate the efflux of electrolytes from the interior of the lens. However, connexins have also been implicated in diffusion of glutathione from the outer cortex to the lens nucleus [17]. Thus, connexins may be involved in bidirectional flux (i.e., metabolites and nutrients into the center of the lens and flux of unwanted ions and byproducts to the periphery), which would be altered by absence of $\mathrm{Cx} 46$ or $\mathrm{Cx} 50$ or by mutations that modify their gap junction function. Indeed, most (but not all) of the cataract-associated connexin mutants characterized to date do not form functional gap junction channels in exogenous expression systems either because they do not traffic properly (and consequently form very few, if any, gap junction plaques) or because they form gap junction plaques that contain non-functional channels (reviewed in [18]).

\section{Differential roles}

The change in the expression pattern of connexins during lens differentiation suggests that connexins may have different roles in lens development and physiology. Indeed, the alterations observed in lenses lacking expression of either Cx50 or Cx46 implicate Cx50 in epithelial cell proliferation and determination of lens size $[6,19,20]$, and $\mathrm{Cx} 46$ in $\mathrm{Ca}^{2+}$ homeostasis in the lens nucleus (alteration of which can lead to activation of $\mathrm{Ca}^{2+}$-dependent proteases) (reviewed in [21]). The role of Cx50 in determining lens size is further supported by heterozygous mice expressing different Cx50 mutants (e.g., Cx50D47A, Cx50S50P, Cx50V64A, and Cx50R205G) [7, 22-24] which have decreased lens sizes (although to different extents).

Cx50 has also been implicated in differentiation. Lenses from homozygous Cx50-null mice or homozygous Cx50G22R and Cx50S50P animals show retention of nuclei in some fiber cell layers that are deeper than normal $[6,25,26]$. In Cx50D47A mice, the alterations in degradation of nuclei and other intracellular organelles are even more pronounced, and they are observed in both homozygotes and heterozygotes [7]. These results suggest that Cx50 may mediate intercellular diffusion of second messengers required for completion of the differentiation process.

Replacement of Cx50 by Cx46 in mice (by a knock-in strategy) rescues lens transparency, but not lens size, further implying differential roles for Cx46 and Cx50 [27]. We do not yet know exactly why Cx46 cannot fully replace the function of $\mathrm{Cx} 50$, but this may relate to differences in the molecules permeating these channels or to differential interactions of these connexins with other lens components.

Gap junction channels formed by lens fiber cell connexins are regulated by voltage, acidification, $\mathrm{Ca}^{2+}$ (likely through interaction with calmodulin [28, 29]), post-translational modifications and certain chemicals (e.g., some alkanols and anesthetics, glycyrrhetinic acid, etc.). Both Cx46 and Cx50 gap junction channels are 
moderately cation-selective $[30,31]$ and have a low permeability to glutathione [17], suggesting that the differential roles rely on permeation of other molecules or on other connexin properties.

\section{Lens connexin function and growth factor signaling pathways}

Some studies suggest that Cx50- (but not Cx46-) mediated gap junctional intercellular communication is increased by activation of the fibroblast growth factor (FGF) transduction pathways [32]. FGFs are among the growth factors that regulate epithelial lens cell proliferation and differentiation [33, 34]. Binding of FGFs to their receptors is transduced by pathways including the PI3K-AKT- and the mitogen-activated protein kinase (MAPK)-signaling pathways. Interestingly, homozygous mice with transgenic expression of a constitutively active mutant of the MAPK kinase 1 (MEK1(E)), which is upstream of MAPK, develop macrophthalmia and cataracts [35]. Deletion of Cx50 or its replacement with Cx46 decreases the MEK1(E)-induced stimulation of post-natal mitosis in the lens, reduces eye and lens growth, and delays the progression of cataracts [32].

In addition, expression of a constitutively active $\mathrm{p} 110 \alpha$ subunit of PI3K with Cx50 or Cx46 in Xenopus oocytes increases $\mathrm{Cx} 50$ (but not $\mathrm{Cx} 46$ ) gap junctional conductance, whereas inhibition of PI3K signaling inhibits Cx50(but not Cx46-) mediated gap junctional conductance [36]. By extrapolation, alterations in PI3K-AKT signaling would be expected to have similar effects on Cx50 in the lens. Homozygous mice with lens-specific deletion of the phosphatase and tensin homolog, PTEN, a protein phosphatase that can antagonize the PI3K-AKT/PKB signaling pathway, develop cataracts and show an AKTdependent decrease in $\mathrm{Na}^{+} / \mathrm{K}^{+}$-ATPase activity [37]. However, the effect of PTEN deletion on lens fiber connexins has not been reported.

These results suggest the presence of a positive feedback circuit between FGF signaling and Cx50 gap junction function that may determine lens size. This hypothesis implies that overexpression of Cx50 accompanied with increased $\mathrm{Cx} 50$ gap junction channel function might result in increased lens size. However, overexpression of Cx50 in mouse primary and secondary lens fiber cells results in slowed differentiation, smaller lenses and cataracts [38]. The reason for the decrease in lens size is unknown, but it may result from the localization of some of the Cx50 in the membrane of intracellular vesicles, which may slow differentiation. Alternatively, to augment lens size the increase in Cx50 gap junction function must occur in lens epithelial cells to influence the proliferation and differentiation of these cells. However, the effect of overexpression of Cx50 in lens epithelial cells has not been tested.

\section{Connexin hemichannels in the normal and cataractous lens}

Lens fiber cell connexins can form functional hemichannels. Rat Cx46 was the first cloned connexin shown to form functional gap junction hemichannels when expressed in Xenopus oocytes [8]. This property is shared with Cx46 orthologues from various species (e.g., human $\mathrm{Cx} 46$, bovine Cx44 and chicken Cx56) [39-41]. Cx50 is much less efficient at forming functional hemichannels; injection of larger amounts of RNA ( $>50$ times) is required to detect hemichannel currents in Xenopus oocytes [42, 43].

Ebihara et al. showed opening of Cx46 hemichannels in isolated lens fiber cells studied at reduced or at normal extracellular $\mathrm{Ca}^{2+}$ concentrations $[44,45]$. The opening of $\mathrm{Cx} 46$ hemichannels at physiological concentrations of $\mathrm{Ca}^{2+}$ may contribute to the $\mathrm{Na}^{+}$leak conductance [45] and provide a pathway for the inward cation leak of the lens circulation model [46]. Because Cx46 hemichannels are mechanosensitive, it has been proposed that they participate in lens accommodation [47].

Although the lens apparently has mechanisms for controlled opening of wild type connexin hemichannels, they may be insufficient to prevent opening of those formed by connexin mutants with enhanced hemichannel activity. Three mutants identified in cataract patients, Cx50G46V, Cx46G143R and Cx46T19M, show increased hemichannel activity in exogenous expressions systems [48-50]. These mutants differ in their ability to form functional gap junction channels. While Cx50G46V elicits similar gap junction channel conductances to wild type Cx50 [48], Cx46G143R shows decreased gap junction channel activity [49] and Cx46T19M does not form functional gap junction channels [50]. Reduced hemichannel function may be pathologic. Cataract-linked connexin mutants (Cx50S276F and Cx50V44A) show decreased hemichannel function and have differential effects on gap junction channel function; Cx50S276F does not form functional gap junction channels [51], whereas Cx50V44A (expressed as a GFP fusion protein) forms functional gap junction channels [52]. However, the signaling pathways by which altered hemichannel activity leads to lens disease have not been identified.

\section{Can the functional defects of connexin mutants be predicted?}

The effects of mutations on function may sometimes be predicted by alignment of the lens connexins with $\mathrm{Cx} 26$ and inferences based on the crystal structure of the Cx26 gap junction channel [53, 54]. The Cx26 crystal structure shows that the N-termini of the six connexins in a hemichannel form a funnel that restricts the diameter at the entrance of the pore. D2 is one of the $\mathrm{N}$-terminal amino acids that lines the surface of the Cx26 pore funnel forming a ring of negatively charged side chains [53, 54]. 
Modeling rat Cx46 based on the Cx26 crystal structure predicts that mutation of the corresponding amino acid in Cx46 (D3) to tyrosine (a bulkier polar amino acid) results in closure or partial closure of the hemichannel in the absence of applied voltage [55]. Indeed, mutation of D3 in human or rat $\mathrm{Cx} 46$ to tyrosine (Cx46D3Y) results in mutants with greatly reduced (or no) hemichannel activity $[55,56]$. The Cx26 model has been recently used to interpret the behavior of $\mathrm{Cx} 46 \mathrm{~N} 188 \mathrm{~T}$, a mutant that forms functional hemichannels, but not gap junction channels in HeLa cells [57]. Residue N188 in Cx46 corresponds to N176 of Cx26. This residue is involved in docking of Cx26 connexons through formation of hydrogen bonds between N176 from a connexon protomer in one cell and K168, T177, and D179 in the counterpart protomer of the connexon in the adjacent cell; the corresponding residues in Cx46 are R180, T189, and D191 (Fig. 2). Thus, replacement of $\mathrm{N} 188$ by $\mathrm{T}$ in $\mathrm{Cx} 46$ would suppress formation of the hydrogen bonds required for connexon docking and thereby abolish gap junction function.

The crystal structure of Cx26 may also be useful in predicting conformational changes affecting protein folding in some mutants and trafficking (by calculating the surface electrostatic potential [58]). However, it may not be able to predict mutations affecting internalization or degradation.

\section{Post-translational modifications of lens fiber connexins}

The roles of connexins in the lens are also affected by posttranslational modifications, which may vary in the different regions of the lens and have different functional effects. Protein cleavage and phosphorylation are considered the most common among the post-translational modifications that can alter channel function of lens connexins.

\section{Cleavage}

Truncation of the C-terminus has been associated with fiber cell maturation [59]. Cleaved connexins are preferentially found in the lens nucleus [59-63], where gap junction plaques are mostly devoid of cholesterol and contain crystalline-packed connexons [64]. Several cleaved forms of Cx46 (with proteolysis in any of its cytoplasmic domains) and Cx50 (with cleavage limited to the C-terminus) have been identified in bovine lenses by mass spectrometry [63], suggesting that these connexins are substrates for more than one protease. Truncation of $\mathrm{Cx} 46$ in the distal C-terminus in the lens cortex and closer to the fourth transmembrane domain in the lens nucleus [63] suggests that the protein goes through sequential and progressive stages of cleavage as cells grow older.

It has been postulated that cleavage of the connexin's C-terminus in mature fiber cells represents an adaptation to maintain functional coupling in the lens nucleus, which has a more acidic $\mathrm{pH}$ than the lens cortex [65]. Indeed, truncation of the mouse Cx46 C-terminus shifts the $\mathrm{pKa}$ for gap junctional conductance to more acidic values, but does not eliminate $\mathrm{pH}$ sensitivity [66]. However, conflicting results have been reported for the $\mathrm{pH}$ sensitivity of truncated Cx50 gap junction channels,

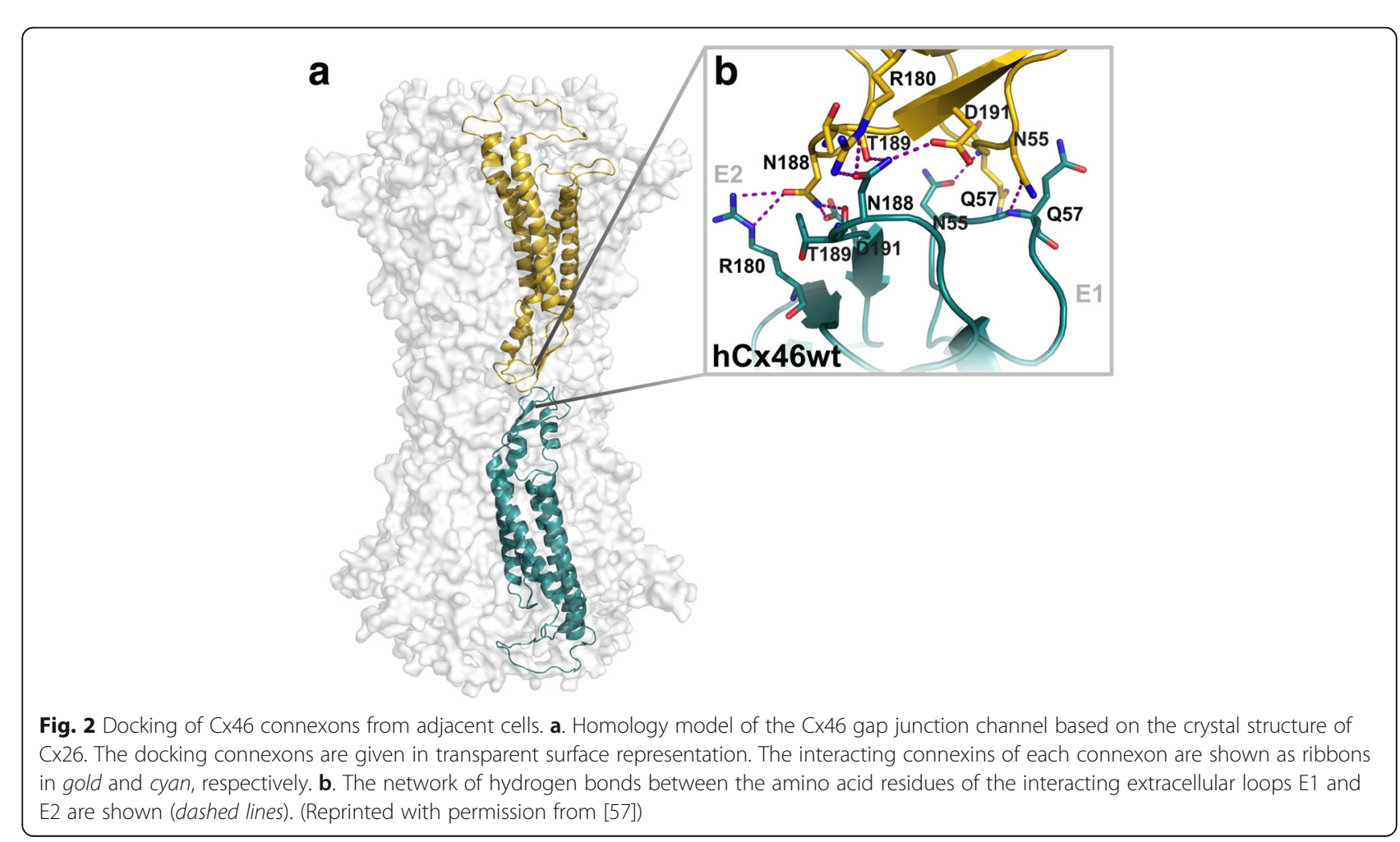


varying from similar to that of full-length $\mathrm{Cx} 50$ to reduced or complete loss of $\mathrm{pH}$ sensitivity [67-70]. The reason for these discrepancies is not clear.

Expression of cleaved forms of Cx46 or Cx50 also decreases total junctional conductance $[66,69,70]$, alters localization of the protein to gap junction plaques and affects intercellular transfer of gap junction tracers [71, 72]. The extent of truncation required to abolish gap junction intercellular communication depends on the connexin subtype and varies in different studies.

Deletion of the last amino acid of $\mathrm{Cx} 50$ (that is important for its interaction with ZO-1; [73]) results in complete loss of gap junction plaque localization and intercellular transfer of Neurobiotin in HeLa cells [71]. Homozygous knock-in mice expressing this Cx50 deletion mutant have smaller lenses with nuclear cataracts, similar to the phenotype of Cx50-null mice [71]. More recently, Wang et al. have suggested that the distal truncation of Cx45.6 (the chicken ortholog of Cx50) protects lens cells against UV radiation [74].

Deletion of the last amino acid of rat $\mathrm{Cx} 46$ leads to a major decrease (but not loss) of localization of the protein at gap junctional plaques and of intercellular coupling [71]. More proximal deletions of rat $\mathrm{Cx} 46$ abolish intercellular transfer of gap junction tracers [71, 72]. In addition, truncation of rat Cx46 after amino acid 284 strongly reduces vesicle budding from gap junction plaques and formation of annular gap junctions, suggesting that the $\mathrm{C}$-terminus modulates the rate of removal of Cx46 from gap junction plaques [72].

\section{Phosphorylation}

All lens connexins are phosphoproteins. Cx43 is phosphorylated at many different sites (reviewed in [75]). Phosphorylation of Cx43 has been implicated in trafficking to and from the plasma membrane, channel function and degradation (reviewed in [75]). Many phosphorylated sites in bovine lens Cx46 and Cx50 have been detected by mass spectrometry $[63,76]$. Phosphorylation of lens fiber connexins has been implicated in regulation of turnover (or stability) and intercellular coupling [77-82]. Three sites involved in these processes have been identified. Phosphorylation of Cx45.6 by casein kinase II at S364 leads to increased turnover of the protein [81], whereas phosphorylation by protein kinase A at S395 has been implicated in increased channel permeability to Lucifer yellow [82]. Protein kinase C (PKC)-dependent phosphorylation of S118 in the intracellular loop of Cx56 correlates with decreased intercellular communication $[78,83]$.

Among the PKC isoforms expressed in the lens, $\mathrm{PKC} Y$ has received special attention, because it is expressed in lens fiber cells and it is activated by the phorbol ester 12-Otetradecanoyl-13 acetate (TPA) [83-85]. Its presence seems essential for phosphorylation of $\mathrm{Cx} 50$ in serines and threonines, because in $\mathrm{PKC} \gamma$ knockout mouse lenses Cx50 lacks phosphorylation in these amino acid residues [86]. These lenses show structural changes in cortical fiber cell gap junctions [86], increased gap junction conductance in differentiating and mature fiber cells [87] and, unlike wild type lenses, their gap junctions remain permeable to Lucifer yellow after treatment with TPA [86]. Lenses from $\mathrm{PKC} Y$ knockout mice show increased levels of $\mathrm{Cx} 43$ (but no changes in total $\mathrm{Cx} 46$ or $\mathrm{Cx} 50$ ); $\mathrm{Cx} 43$ is present not only in the epithelium but also in differentiating fiber cells [87]. TPA-induced activation of PKC causes a proteasomedependent decrease in $\mathrm{Cx} 43$ in epithelial cells that correlates with an increase in both mRNA and protein levels of Cx46 [88]. Overexpression of Cx46 leads to a proteasomedependent decrease in $\mathrm{Cx} 43$ protein levels in these cells. The exact mechanism underlying these changes is not completely understood.

\section{Ubiquitylation}

Ubiquitylation is another post-translational modification that has been demonstrated for $\mathrm{Cx} 43$ and $\mathrm{Cx} 45.6[89,90]$. Transgenic expression of a mutant ubiquitin (K6W) that is conjugation competent but proteolytically incompetent in mice leads to cataracts that are associated with an increase in Cx43, a decrease in Cx46 and in intercellular coupling between fiber cells in the lens nucleus, and accumulation of calcium in the lens core (likely as a result of decreased gap junction activity) [91]. Since overexpression of K6W ubiquitin slows epithelial cell proliferation and differentiation [92], the changes in $\mathrm{Cx} 43$ and $\mathrm{Cx} 46$ levels may result at least in part from altered epithelial-tofiber cell differentiation.

Different post-translational modifications can influence each other. For example, the caspase-3-dependent cleavage of Cx45.6 is inhibited by casein kinase II-mediated phosphorylation of Ser364 [93]. Post-translational modifications of connexins are tightly regulated, regionalized and/or progressive and help to maintain lens transparency. Therefore, mutations that alter or create novel recognition sites for phosphorylation, cleavage, ubiquitylation or other post-translational modifications may affect connexin function and lead to cataracts.

\section{Possible mechanisms for the inheritance pattern of cataracts}

Many mutations of Cx46 and Cx50 have been linked to congenital cataracts (summarized in Fig. 3). Most Cx46 and Cx50 gene variants are inherited as autosomal dominant traits, but some of them have been linked to recessive and age-related cataracts in humans.

\section{Congenital cataracts}

Considering that many of the cataract-associated mutants characterized in exogenous expression systems show loss 

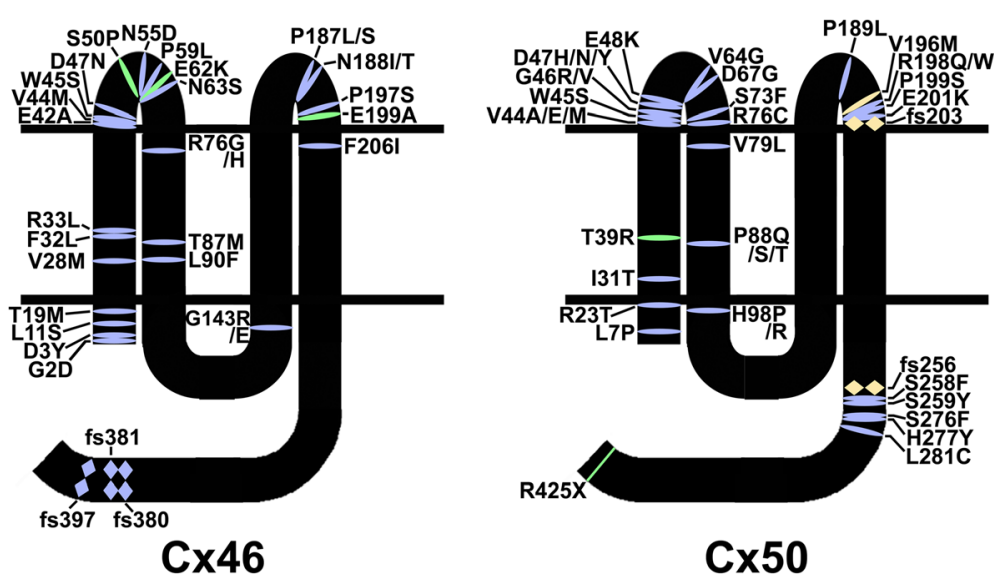

Fig. 3 Depiction of cataract mutants in human Cx46 and Cx50. Diagrams show the membrane topology of Cx46 and Cx50 and the localization of Cx46 and Cx50 mutants found in patients with non-syndromic and syndromic cataracts. The diagrams do not include mutations predisposing to age-related cataracts. Missense mutations are represented by a fusiform shape; frame-shift mutations (fs) are depicted by double rhombi; and early termination mutations by rectangles. Cx46 and Cx50 mutants with autosomal dominant inheritance are represented in light blue-purple. Mutants with recessive inheritance are shown in light golden yellow and mutants with an unassigned or sporadic inheritance pattern are shown in green. For different missense mutations at the same amino acid residue, the color coding depicts a known inheritance pattern (even if it is unassigned for the other missense mutations at that site). The Cx501247M mutant has not been depicted, because it may be a polymorphism. These diagrams are based on the information available in Cat-Map ([2]; http://cat-map.wustl.edu/)

of function (and only some of them have a dominant negative effect on co-expressed wild type connexins) and that mice with half of the Cx46 or Cx50 levels (heterozygous null mice) do not develop cataracts $[19,94]$, it is intriguing that most $\mathrm{Cx} 46$ and $\mathrm{Cx} 50$ mutants cause dominant cataracts. Studies on some mouse lines carrying a cataract-linked $\mathrm{Cx} 50$ or $\mathrm{Cx} 46$ mutation have revealed alterations in the co-expressed connexin. Homozygous mice for Cx50G22R show altered distribution and reduced phosphorylation of Cx46 [95]. In Cx50D47A and Cx46fs380 mice, heterozygous and homozygous lenses show a severe reduction in the levels of the connexin (mutant and wild type) and a significant but milder reduction in the co-expressed lens fiber connexin [7, 96]. Whether the change in the co-expressed connexin is due to direct interaction with the mutant or an indirect effect (e.g., the mutation affects interactions with other lens components necessary for normal behavior of the coexpressed connexin) remains to be determined. Levels of spliced Xbp-1 transcripts in mouse lenses expressing Cx50G22R (which causes autosomal semi-dominant cataracts) are elevated in newborn heterozygotes and at 2 months of age in heterozygotes and homozygotes [26]. Cx50D47A induces ER stress, triggering activation of the PERK-ATF4 pathway [97]. These results suggest that signaling pathways of the unfolded protein response may contribute to cataract. Thus, alterations in the coexpressed wild type connexin or induction of ER stress could explain the dominant inheritance.

As a corollary, a recessive inheritance pattern would imply that the mutant does not affect the co-expressed connexin and/or the interactions with other lens components that may affect lens transparency. Characterization of one of such mutant, Cx50fs (or fs256 as termed in Fig. 3), revealed that it is actively degraded through endoplasmic reticulum-associated degradation [98].

\section{Age-related cataracts}

Polymorphisms in the intronic region of the Cx50 gene and a C-to-G transversion at position -39 (c. $-39 \mathrm{C}>\mathrm{G}$ ) in the Cx46 gene may be associated with age-related cataracts in the Chinese population $[99,100]$. The exact mechanism by which these mutations predispose people to age-related cataracts is unclear. However, considering that the encoded protein is normal and that a $50 \%$ decrease in $\mathrm{Cx} 46$ or $\mathrm{Cx} 50$ in mouse lenses does not affect transparency, one could speculate that mutations in the non-coding regions may affect the level of expression of the connexin to a value that is insufficient to cause cataracts early in life but the sustained alteration over long periods of time becomes more significant and leads to opacities.

A slight association between some haplotype variations in the coding region of the $\mathrm{Cx} 46$ and $\mathrm{Cx} 50$ genes (Cx46V139M and Cx50V275I) and development of agerelated cataract in the Chinese population has been reported [100]. In silico analysis predicts that these mutations are benign [100]. These mutants have not been tested for effects on connexin function. If they have an effect, and because of the age of appearance of cataracts, they would be expected to have a mild effect on channel function, alterations in post-translational modifications or interactions with other lens components. This raises 
the possibility that in the potential case of homozygosity some of them could lead to cataracts earlier in life.

\section{Effects of targeted deletion or expression of mutants of other proteins on lens connexins}

Because connexin molecules are involved in networks of interaction and signaling molecules, alterations in other lens components could affect levels, distribution and/or function of connexins. This has been evaluated in some mouse models with null or missense mutations of other lens proteins including $\gamma$-crystallins, protein kinases, cytoskeletal proteins, MP20, etc. A diagram of lens proteins that interact with Cx46 and Cx50 is shown in Fig. 4. We will review some of these studies.

\section{$\gamma$-Crystallins}

Crystallins are the predominant cytoplasmic proteins that help maintain the proper refractive properties of the lens. Changes in their levels, solubility or abundance of cleaved/modified forms have been associated with cataracts. Many of the mouse models of cataract with targeted deletion of $\mathrm{Cx} 46$ or $\mathrm{Cx} 50$ or expressing a mutant of these connexins show alterations in lens crystallins [7, 19, 94, 96, 101]. In turn, heterozygous and homozygous mice expressing the V76D $\gamma \mathrm{D}$-crystallin mutant [102] and 10-day (but not 1-day) old homozygous S11R $\gamma B$-crystallin mice [103] show decreased levels of Cx46 and Cx50. How mutations in $\gamma$-crystallins, which are synthesized during differentiation and maturation of lens fiber cells, lead to decreased connexin levels is unknown, but it has been suggested that it may relate to the disruption of membrane-cytoskeleton structures of inner fiber cells in the case of homozygous S11R $\gamma \mathrm{B}$-crystallin mice and to incomplete fiber cell differentiation in mice expressing V76D $\gamma \mathrm{D}$-crystallin $[102,103]$.

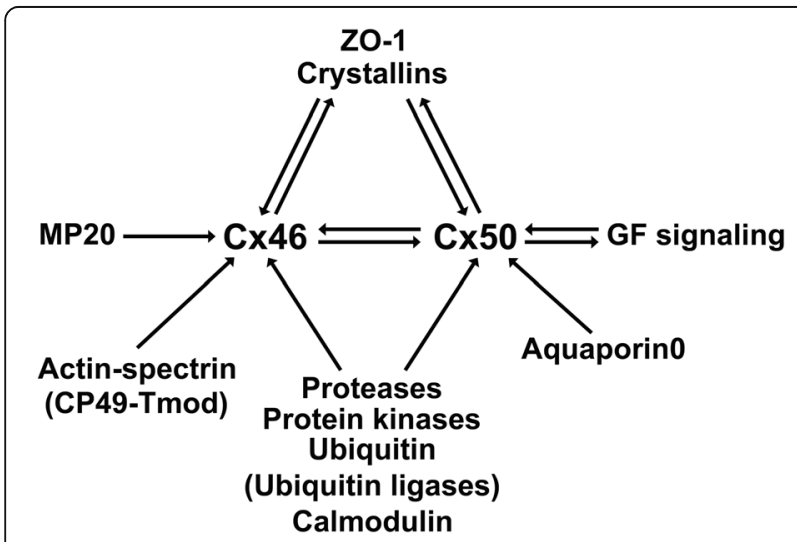

Fig. 4 Interaction of fiber cell connexins with other lens components. The diagram depicts proteins which either interact with $C \times 46$ and/or Cx50, or are affected by mutations in $\mathrm{C} \times 46$ or $\mathrm{Cx} 50$, or whose mutations affect $C \times 46$ or $C \times 50$ (as described in the text). The interaction of $C \times 50$ with aquaporin0 is based on the report by Yu et al. [115]

\section{Cytoskeleton}

Lens gap junction plaques rest in lacunae of the membrane-associated actin-spectrin network [104]. Disruption of this network by deletion of both phakinin (also known as CP49) and tropomodulin in mice leads to a decrease in the size of Cx46-containing gap junction plaques in differentiating fiber cells without changing the total levels of this connexin [104]. These lenses do not show cataracts at 2 months of age, but show increased light scattering and decreased coupling conductance $[104,105]$. It has been suggested that disruption of the actin-spectrin network may interfere with formation or stability of large Cx46 gap junction plaques [104].

\section{MP20}

Lim2 (also known as MP20), a claudin-like protein, is the second most abundant integral membrane protein in the lens [13]. Its function is not clear, but it may have an adhesive role, because it is inserted in the plasma membrane in a region of the lens that is impenetrable to extracellular tracers [106]. Deletion of Lim2 decreases Cx46 levels by $~ 50 \%$ in the core of the lens, whereas the levels are similar to wild type mice in the cortex [107]. These changes are associated with $\sim 55 \%$ decrease in cell-cell coupling in differentiating and mature fibers, suggesting that the decrease in intercellular coupling in the lens core may result from reduced Cx46 levels, whereas that in the outer cell layers may ensue from absence of cell fusions $[107,108]$.

Collectively, these results attest to the multiple effects that can be caused by alterations in one particular lens component. While some of these are direct, others are considered secondary or indirect to such alteration.

\section{Conclusions}

In conclusion, lens gap junction channels and connexin hemichannels are important for lens homeostasis, function and transparency. These channels have connexin subtype-specific properties and regulation. They participate in intercellular signaling via gap junction channels and may contribute to autocrine/paracrine signaling through hemichannels. At the same time, connexins can be substrates for the effectors of the signaling pathways and undergo post-translational modifications that may alter their function. Depending on the functional effect induced, this could represent a positive or a negative feedback circuit.

The effects of expression of a lens connexin mutant in the mouse on other lens components suggest that lens connexins are involved in networks of protein interactions and signaling pathways. This raises the possibility that some connexin mutants with minor (or no) effects on connexin channel function (as assessed in exogenous 
expression systems) may lead to cataracts by affecting other aspects of the connexin functions in the lens (e.g., the interaction with other lens proteins).

With the advent of in vitro cell culture systems that mimic lens fiber cell differentiation starting from embryonic stem cells $[109,110]$, it may be possible to investigate further the role of wild type connexins in lens development and differentiation and the regulation of connexin functions by different growth factors and signaling pathways at different stages of cell differentiation. Since these lentoid-forming experimental systems may be suitable for genetic manipulation, they could also be used to study the temporal course of the changes induced by altering levels or function of fiber cell connexins on other lens components as well as the mechanisms by which mutant connexins lead to cataracts as long as they faithfully recapitulate what happens in the lens in vivo.

\section{Acknowledgements}

Figure 2 is part of a publication: doi: 10.1016/j.bbamem.2015.10.001. The reusage is covered by licence number 3858220569578 .

\section{Declarations}

This article has been published as part of BMC Cell Biology Volume 18 Supplement 1, 2017: Proceedings of the International Gap Junction Conference 2015: second issue. The full contents of the supplement are available online at http://bmccellbiol.biomedcentral.com/articles/ supplements/volume-18-supplement-1.

\section{Funding}

This article was funded by US National Institutes of Health Grant RO1EY08368 and The DFG Sonderforschungsbereich / Transregio 37.

\section{Availability of data and material}

Not applicable.

\section{Author's contributions}

VMB and AN wrote the manuscript and approved the final version.

\section{Competing interests}

The authors declare that they have no competing interests.

\section{Consent for publication}

Not applicable.

\section{Ethics approval and consent to participate}

Not applicable.

\section{Published: 17 January 2017}

\section{References}

1. Goodenough DA. The crystalline lens. A system networked by gap junctional intercellular communication. Semin Cell Biol. 1992:3:49-58.

2. Shiels A, Bennett TM, Hejtmancik JF. Cat-Map: putting cataract on the map. Mol Vis. 2010;16:2007-15.

3. Jiang JX. Gap junctions or hemichannel-dependent and independent roles of connexins in cataractogenesis and lens development. Curr Mol Med. 2010;10:851-63.

4. Rao PV. The pulling, pushing and fusing of lens fibers. Cell Adhes Migr. 2008:2:170-3.

5. Beyer EC, Kistler J, Paul DL, Goodenough DA. Antisera directed against connexin43 peptides react with a 43-kD protein localized to gap junctions in myocardium and other tissues. J Cell Biol. 1989;108:595-605.

6. Rong P, Wang X, Niesman I, Wu Y, Benedetti LE, Dunia I, Levy E, Gong X. Disruption of Gja8 (a8 connexin) in mice leads to microphthalmia associated with retardation of lens growth and lens fiber maturation. Development. 2002:129:167-74.

7. Berthoud VM, Minogue PJ, Yu H, Schroeder R, Snabb Jl, Beyer EC. Connexin50D47A decreases levels of fiber cell connexins and impairs lens fiber cell differentiation. Invest Ophthalmol Vis Sci. 2013;54:7614-22.

8. Paul DL, Ebihara L, Takemoto L, Swenson Kl, Goodenough DA. Connexin46, a novel lens gap junction protein, induces voltage-gated currents in nonjunctional plasma membrane of Xenopus oocytes. J Cell Biol. 1991;115:1077-89.

9. White TW, Bruzzone R, Goodenough DA, Paul DL. Mouse Cx50, a functional member of the connexin family of gap junction proteins, is the lens fiber protein MP70. Mol Biol Cell. 1992;3:711-20.

10. lovine MK, Gumpert A, Falk M, Mendelson TC. Cx23, a connexin with only four extracellular-loop cysteines, forms functional gap junction channels and hemichannels. FEBS Lett. 2008;582:165-70.

11. Gustincich S, Batalov S, Beisel KW, Bono H, Carninci P, Fletcher CF, Grimmond S, Hirokawa N, Jarvis ED, Jegla T, et al. Analysis of the mouse transcriptome for genes involved in the function of the nervous system. Genome Res. 2003;13:1395-401.

12. Sonntag S, Söhl G, Dobrowolski R, Zhang J, Theis M, Winterhager E, Bukauskas FF, Willecke K. Mouse lens connexin23 (Gjel) does not form functional gap junction channels but causes enhanced ATP release from HeLa cells. Eur J Cell Biol. 2009;88:65-77.

13. Bassnett S, Wilmarth PA, David LL. The membrane proteome of the mouse lens fiber cell. Mol Vis. 2009;15:2448-63.

14. Berthoud VM, Minogue PJ, Snabb Jl, Dzhashiashvili Y, Novak LA, Zoltoski RK, Popko B, Beyer EC. Connexin23 deletion does not affect lens transparency. Exp Eye Res. 2016;146:283-8.

15. Mathias RT, Kistler J, Donaldson P. The lens circulation. J Membr Biol. 2007;216:1-16.

16. Vaghefi E, Malcolm DT, Jacobs MD, Donaldson PJ. Development of a 3D finite element model of lens microcirculation. Biomed Eng Online. 2012;11:69.

17. Slavi N, Rubinos C, Li L, Sellitto C, White TW, Mathias R, Srinivas M. Connexin 46 (CX46) gap junctions provide a pathway for the delivery of glutathione to the lens nucleus. J Biol Chem. 2014;289:32694-702.

18. Beyer EC, Ebihara L, Berthoud VM. Connexin mutants and cataracts. Front Pharmacol. 2013:4:43.

19. White TW, Goodenough DA, Paul DL. Targeted ablation of connexin50 in mice results in microphthalmia and zonular pulverulent cataracts. J Cell Biol. 1998;143:815-25.

20. Sellitto C, Li L, White TW. Connexin50 is essential for normal postnatal lens cell proliferation. Invest Opthalmol Vis Sci. 2004;45:3196-202.

21. Gao J, Sun X, Martinez-Wittinghan FJ, Gong X, White TW, Mathias RT. Connections between connexins, calcium, and cataracts in the lens. J Gen Physiol. 2004;124:289-300.

22. Graw J, Löster J, Soewarto D, Fuchs H, Meyer B, Reis A, Wolf E, Balling R, Hrabé de Angelis M. Characterization of a mutation in the lens-specific MP70 encoding gene of the mouse leading to a dominant cataract. Exp Eye Res. 2001;73:867-76.

23. Xia C-h, Liu H, Cheung D, Cheng C, Wang E, Du X, Beutler B, Lo W-K, Gong $X$. Diverse gap junctions modulate distinct mechanisms for fiber cell formation during lens development and cataractogenesis. Development. 2006;133:2033-40

24. Xia C-h, Chang B, DeRosa AM, Cheng C, White TW, Gong X. Cataracts and microphthalmia caused by a Gja8 mutation in extracellular loop 2. PLoS One. 2012;7:e52894.

25. Dunia I, Cibert C, Gong X, Xia C-h, Recouvreur M, Levy E, Kumar N, Bloemendal H, Benedetti EL. Structural and immunocytochemical alterations in eye lens fiber cells from Cx46 and Cx50 knockout mice. Eur J Cell Biol. 2006:85:729-52.

26. Alapure BV, Stull JK, Firtina Z, Duncan MK. The Unfolded Protein Response is activated in Connexin 50 mutant mouse lenses. Exp Eye Res. 2012;102:28-37.

27. White TW. Unique and redundant connexin contributions to lens development. Science. 2002;295:319-20.

28. Zhou Y, Yang W, Lurtz MM, Chen Y, Jiang J, Huang Y, Louis CF, Yang JJ. Calmodulin mediates the $\mathrm{Ca}^{2+}$-dependent regulation of $\mathrm{C} \times 44$ gap junctions. Biophys J. 2009;96:2832-48.

29. Chen Y, Zhou Y, Lin X, Wong HC, Xu Q, Jiang J, Wang S, Lurtz MM, Louis CF, Veenstra RD, Yang JJ. Molecular interaction and functional regulation of connexin50 gap junctions by calmodulin. Biochem J. 2011;435:711-22.

30. Srinivas M, Costa M, Gao Y, Fort A, Fishman GI, Spray DC. Voltage dependence of macroscopic and unitary currents of gap junction channels 
formed by mouse connexin50 expressed in rat neuroblastoma cells. J Physiol. 1999;517:673-89.

31. Trexler EB, Bukauskas FF, Kronengold J, Bargiello TA, Verselis VK. The first extracellular loop domain is a major determinant of charge selectivity in connexin46 channels. Biophys J. 2000;79:3036-51.

32. Shakespeare TI, Sellitto C, Li L, Rubinos C, Gong X, Srinivas M, White TW. Interaction between connexin50 and mitogen-activated protein kinase signaling in lens homeostasis. Mol Biol Cell. 2009;20:2582-92.

33. Chamberlain CG, MCAvoy JW. Evidence that fibroblast growth factor promotes lens fibre differentiation. Curr Eye Res. 1987;6:1165-9.

34. Chamberlain CG, McAvoy JW. Induction of lens fibre differentiation by acidic and basic fibroblast growth factor (FGF). Growth Factors. 1989;1:125-34.

35. Gong X, Wang X, Han J, Niesman I, Huang Q, Horwitz J. Development of cataractous macrophthalmia in mice expressing an active MEK1 in the lens. Invest Ophthalmol Vis Sci. 2001;42:539-48.

36. Martinez JM, Wang $\mathrm{H}-\mathrm{Z}$, Lin RZ, Brink PR, White TW. Differential regulation of Connexin50 and Connexin46 by PI3K signaling. FEBS Lett. 2015;589:1340-5.

37. Sellitto C, Li L, Gao J, Robinson ML, Lin RZ, Mathias RT, White TW. AKT activation promotes PTEN hamartoma tumor syndrome-associated cataract development. J Clin Invest. 2013;123:5401-9.

38. Chung J, Berthoud VM, Novak L, Zoltoski R, Heilbrunn B, Minogue PJ, Liu X, Ebihara L, Kuszak J, Beyer EC. Transgenic overexpression of connexin50 induces cataracts. Exp Eye Res. 2007;84:513-28.

39. Gupta VK, Berthoud VM, Atal N, Jarillo JA, Barrio LC, Beyer EC. Bovine connexin44, a lens gap junction protein: molecular cloning, immunologic characterization, and functional expression. Invest Ophthalmol Vis Sci. 1994;35:3747-58

40. Ebihara L, Berthoud VM, Beyer EC. Distinct behavior of connexin56 and connexin46 gap junctional channels can be predicted from the behavior of their hemi-gap-junctional channels. Biophys J. 1995;68:1796-803.

41. Pal JD, Liu X, Mackay D, Shiels A, Berthoud VM, Beyer EC, Ebihara L. Connexin46 mutations linked to congenital cataract show loss of gap junction channel function. Am J Physiol Cell Physiol. 2000;279:C596-602.

42. Zampighi GA, Loo DD, Kreman M, Eskandari S, Wright EM. Functional and morphological correlates of connexin50 expressed in Xenopus laevis oocytes. J Gen Physiol. 1999;113:507-24.

43. Beahm DL, Hall JE. Hemichannel and junctional properties of connexin 50 . Biophys J. 2002;82:2016-31.

44. Ebihara L, Tong J-J, Vertel B, White TW, Chen T-L. Properties of connexin 46 hemichannels in dissociated lens fiber cells. Invest Ophthalmol Vis Sci. 2011:52:882-9.

45. Ebihara L, Korzyukov Y, Kothari S, Tong J-J. CX46 hemichannels contribute to the sodium leak conductance in lens fiber cells. Am J Physiol Cell Physiol. 2014:306:C506-13.

46. Donaldson P, Kistler J, Mathias RT. Molecular solutions to mammalian lens transparency. Physiology. 2001;16:118-23.

47. Bao L, Sachs F, Dahl G. Connexins are mechanosensitive. Am J Physiol Cell Physiol. 2004;287:C1389-95.

48. Minogue PJ, Tong J-J, Arora A, Russell-Eggitt I, Hunt DM, Moore AT, Ebihara L, Beyer EC, Berthoud VM. A mutant connexin50 with enhanced hemichannel function leads to cell death. Invest Ophthalmol Vis Sci. 2009:50:5837-45.

49. Ren Q, Riquelme MA, Xu J, Yan X, Nicholson BJ, Gu S, Jiang JX. Cataractcausing mutation of human connexin 46 impairs gap junction, but increases hemichannel function and cell death. PLoS One. 2013;8:e74732.

50. Tong J-J, Minogue PJ, Kobeszko M, Beyer EC, Berthoud VM, Ebihara L. The connexin46 mutant, CX46T19M, causes loss of gap junction function and alters hemi-channel gating. J Membr Biol. 2014;248:145-55.

51. Liu Y, Qiao C, Wei T, Zheng F, Guo S, Chen Q, Yan M, Zhou X. Mutant connexin 50 (S276F) inhibits channel and hemichannel functions inducing cataract. J Genet. 2015;94:221-9.

52. Zhu Y, Yu H, Wang W, Gong X, Yao K. A novel GJA8 mutation (p.V44A) causing autosomal dominant congenital cataract. PLoS One. 2014;9:e115406.

53. Maeda S, Tsukihara T. Structure of the gap junction channel and its implications for its biological functions. Cell Mol Life Sci. 2010;68:1115-29.

54. Nakagawa S, Maeda S, Tsukihara T. Structural and functional studies of gap junction channels. Curr Opin Struct Biol. 2010;20:423-30.

55. Tong J-J, Sohn BCH, Lam A, Walters DE, Vertel BM, Ebihara L. Properties of two cataract-associated mutations located in the $\mathrm{NH} 2$ terminus of connexin 46. Am J Physiol Cell Physiol. 2013;304:C823-32.

56. Schlingmann B, Schadzek P, Busko S, Heisterkamp A, Ngezahayo A. Cataract-associated D3Y mutation of human connexin46 ( $h$ CX46) increases the dye coupling of gap junction channels and suppresses the voltage sensitivity of hemichannels. J Bioenerg Biomembr. 2012;44:607-14.

57. Schadzek P, Schlingmann B, Schaarschmidt F, Lindner J, Koval M, Heisterkamp A, Preller M, Ngezahayo A. The cataract related mutation N188T in human connexin46 ( $h$ Cx46) revealed a critical role for residue N188 in the docking process of gap junction channels. Biochim Biophys Acta. 2016;1858:57-66.

58. Sarkar D, Ray K, Sengupta M. Structure-function correlation analysis of connexin50 missense mutations causing congenital cataract: electrostatic potential alteration could determine intracellular trafficking fate of mutants. BioMed Res Int. 2014;2014:673895.

59. Lin JS, Fitzgerald S, Dong Y, Knight C, Donaldson P, Kistler J. Processing of the gap junction protein connexin50 in the ocular lens is accomplished by calpain. Eur J Cell Biol. 1997;73:141-9.

60. Voorter CEM, Kistler J. CAMP-dependent protein kinase phosphorylates gap junction protein in lens cortex but not in lens nucleus. Biochim Biophys Acta. 1989:986:8-10.

61. Yin X, Gu S, Jiang JX. Regulation of lens connexin 45.6 by apoptotic protease, caspase-3. Cell Commun Adhes. 2001;8:373-6.

62. Wang Z, Han J, Schey KL. Spatial differences in an integral membrane proteome detected in laser capture microdissected samples. J Proteome Res. 2008;7:2696-702.

63. Wang Z, Schey KL. Phosphorylation and truncation sites of bovine lens connexin 46 and connexin 50. Exp Eye Res. 2009;89:898-904

64. Biswas SK, Jiang JX, Lo W-K. Gap junction remodeling associated with cholesterol redistribution during fiber cell maturation in the adult chicken lens. Mol Vis. 2009;15:1492-508.

65. Mathias RT, Riquelme G, Rae JL. Cell to cell communication and pH in the frog lens. J Gen Physiol. 1991;98:1085-103.

66. Eckert R. pH gating of lens fibre connexins. Pflüg Arch. 2002;443:843-51.

67. Lin JS, Eckert R, Kistler J, Donaldson P. Spatial differences in gap junction gating in the lens are a consequence of connexin cleavage. Eur J Cell Biol. 1998; 76:246-50

68. Stergiopoulos K, Alvarado JL, Mastroianni M, Ek-Vitorin JF, Taffet SM, Delmar M. Hetero-domain interactions as a mechanism for the regulation of connexin channels. Circ Res. 1999:84:1144-55.

69. Xu X, Berthoud VM, Beyer EC, Ebihara L. Functional role of the carboxyl terminal domain of human connexin 50 in gap junctional channels. J Membr Biol. 2002;186:101-12.

70. DeRosa AM, Mui R, Srinivas M, White TW. Functional characterization of a naturally occurring Cx50 truncation. Invest Ophthalmol Vis Sci. 2006;47:4474-81.

71. Chai Z, Goodenough DA, Paul DL. Cx50 requires an intact PDZ-binding motif and ZO-1 for the formation of functional intercellular channels. Mol Biol Cell. 2011;22:4503-12.

72. Schlingmann B, Schadzek P, Hemmerling F, Schaarschmidt F, Heisterkamp A, Ngezahayo A. The role of the C-terminus in functional expression and internalization of rat connexin46 (rCx46). J Bioenerg Biomembr. 2012;45:59-70.

73. Nielsen PA, Baruch A, Shestopalov VI, Giepmans BN, Dunia I, Benedetti EL, Kumar NM. Lens connexins a3Cx46 and a8C $\times 50$ interact with zonula occludens protein-1 (ZO-1). Mol Biol Cell. 2003;14:2470-81.

74. Wang K, Gu S, Yin X, Weintraub ST, Hua Z, Jiang JX. Developmental truncations of connexin 50 by caspases adaptively regulate gap junctions/ hemichannels and protect lens cells against ultraviolet radiation. J Biol Chem. 2012;287:15786-97.

75. Solan JL, Lampe PD. Specific Cx43 phosphorylation events regulate gap junction turnover in vivo. FEBS Lett. 2014;588:1423-9.

76. Shearer D, Ens W, Standing K, Valdimarsson G. Posttranslational modifications in lens fiber connexins identified by off-line-HPLC MALDI-quadrupole time-of-flight mass spectrometry. Invest Opthalmol Vis Sci. 2008;49:1553-62.

77. Berthoud VM, Cook AJ, Beyer EC. Characterization of the gap junction protein connexin56 in the chicken lens by immunofluorescence and immunoblotting. Invest Ophthalmol Vis Sci. 1994;35:4109-17.

78. Berthoud VM, Beyer EC, Kurata WE, Lau AF, Lampe PD. The gap-junction protein connexin 56 is phosphorylated in the intracellular loop and the carboxy-terminal region. Eur J Biochem. 1997;244:89-97.

79. Berthoud VM, Bassnett S, Beyer EC. Cultured chicken embryo lens cells resemble differentiating fiber cells in vivo and contain two kinetic pools of connexin56. Exp Eye Res. 1999:68:475-84.

80. TenBroek EM, Louis CF, Johnson R. The differential effects of 12-Otetradecanoylphorbol-13-acetate on the gap junctions and connexins of the developing mammalian lens. Dev Biol. 1997;191:88-102. 
81. Yin X, Jedrzejewski PT, Jiang JX. Casein kinase II phosphorylates lens connexin 45.6 and is involved in its degradation. J Biol Chem. 2000;275:6850-6

82. Liu J, Ek Vitorin JF, Weintraub ST, Gu S, Shi Q, Burt JM, Jiang JX. Phosphorylation of connexin 50 by protein kinase A enhances gap junction and hemichannel function. J Biol Chem. 2011;286:16914-28.

83. Berthoud VM, Westphale EM, Grigoryeva A, Beyer EC. PKC isoenzymes in the chicken lens and TPA-induced effects on intercellular communication. Invest Ophthalmol Vis Sci. 2000;41:850-8.

84. Saleh SM, Takemoto LJ, Zoukhri D, Takemoto DJ. PKC- $\gamma$ phosphorylation of connexin 46 in the lens cortex. Mol Vis. 2001;7:240-6.

85. Zampighi GA, Planells AM, Lin D, Takemoto D. Regulation of lens cell-to-cell communication by activation of PKCY and disassembly of Cx50 channels. Invest Ophthalmol Vis Sci. 2005;46:3247-55.

86. Lin D, Barnett M, Lobell S, Madgwick D, Shanks D, Willard L, Zampighi GA Takemoto DJ. PKCy knockout mouse lenses are more susceptible to oxidative stress damage. J Exp Biol. 2006:209:4371-8.

87. Das S, Wang H, Molina SA, Martinez-Wittinghan FJ, Jena S, Bossmann LK, Miller KA, Mathias RT, Takemoto DJ. PKC , role in lens differentiation and gap junction coupling. Curr Eye Res. 2011;36:620-31.

88. Banerjee D, Das S, Molina SA, Madgwick D, Katz MR, Jena S, Bossmann LK, Pal D, Takemoto DJ. Investigation of the reciprocal relationship between the expression of two gap junction connexin proteins, connexin46 and connexin43. J Biol Chem. 2011;286:24519-33.

89. Laing JG, Beyer EC. The gap junction protein connexin43 is degraded via the ubiquitin proteasome pathway. J Biol Chem. 1995;270:26399-403.

90. Yin X, Liu J, Jiang JX. Lens fiber connexin turnover and caspase-3mediated cleavage are regulated alternately by phosphorylation. Cell Commun Adhes. 2008;15:1-11.

91. Liu K, Lyu L, Chin D, Gao J, Sun X, Shang F, Caceres A, Chang M-L, Rowan S, Peng J, et al. Altered ubiquitin causes perturbed calcium homeostasis, hyperactivation of calpain, dysregulated differentiation, and cataract. Proc Natl Acad Sci U S A. 2015;112:1071-6.

92. Caceres A, Shang F, Wawrousek E, Liu Q, Avidan O, Cvekl A, Yang Y, Haririnia A, Storaska A, Fushman D, et al. Perturbing the ubiquitin pathway reveals how mitosis is hijacked to denucleate and regulate cell proliferation and differentiation in vivo. PLoS One. 2010;5:e13331.

93. Yin X, Gu S, Jiang JX. The development-associated cleavage of lens connexin 45.6 by caspase-3-like protease is regulated by casein kinase IImediated phosphorylation. J Biol Chem. 2001;276:34567-72.

94. Gong X, Li E, Klier G, Huang Q, Wu Y, Lei H, Kumar NM, Horwitz J, Gilula NB. Disruption of a3 connexin gene leads to proteolysis and cataractogenesis in mice. Cell. 1997;91:833-43.

95. Chang B, Wang X, Hawes NL, Ojakian R, Davisson MT, Lo W-K, Gong X. A Gja8 (Cx50) point mutation causes an alteration of a3 connexin ( $\mathrm{C} 46)$ in semi-dominant cataracts of Lop10 mice. Hum Mol Genet. 2002;11:507-13.

96. Berthoud VM, Minogue PJ, Yu H, Snabb Jl, Beyer EC. Connexin46fs380 causes progressive cataracts. Invest Ophthalmol Vis Sci. 2014;55:6639-48.

97. Berthoud VM, Minogue PJ, Lambert PA, Snabb JI, Beyer EC. The cataractlinked mutant connexin50D47A causes endoplasmic reticulum stress in mouse lenses. J Biol Chem. 2016;291:17569-78.

98. Minogue PJ, Beyer EC, Berthoud VM. A connexin50 mutant, Cx50fs, that causes cataracts is unstable, but is rescued by a proteasomal inhibitor. J Biol Chem. 2013;288:20427-34.

99. Liu Y, Ke M, Yan M, Guo S, Mothobi ME, Chen Q, Zheng F. Association between gap junction protein-alpha 8 polymorphisms and age-related cataract. Mol Biol Rep. 2011;38:1301-7.

100. Zhou Z, Wang B, Hu S, Zhang C, Ma X, Qi Y. Genetic variations in GJA3, GJA8, LIM2, and age-related cataract in the Chinese population: a mutation screening study. Mol Vis. 2011;17:621-6.

101. Xia C-h, Cheng C, Huang Q, Cheung D, Li L, Dunia I, Benedetti LE, Horwitz J, Gong X. Absence of a3 (Cx46) and a8 (Cx50) connexins leads to cataracts by affecting lens inner fiber cells. Exp Eye Res. 2006;83:688-96.

102. Wang K, Cheng C, Li L, Liu H, Huang Q, Xia C-h, Yao K, Sun P, Horwitz J, Gong X. yD-Crystallin-associated protein aggregation and lens fiber cell denucleation. Invest Opthalmol Vis Sci. 2007:48:3719-28.

103. Li L, Chang B, Cheng C, Chang D, Hawes NL, Xia C-h, Gong X. Dense nuclear cataract caused by the $\mathrm{\gamma B}-$-Crystallin S11R point mutation. Invest Ophthalmol Vis Sci. 2008;49:304-9.

104. Cheng C, Nowak RB, Gao J, Sun X, Biswas SK, Lo W-K, Mathias RT, Fowler VM. Lens ion homeostasis relies on the assembly and/or stability of large connexin 46 gap junction plaques on the broad sides of differentiating fibe cells. Am J Physiol Cell Physiol. 2015;308:C835-47.

105. Gokhin DS, Nowak RB, Kim NE, Arnett EE, Chen AC, Sah RL, Clark Jl, Fowler VM. Tmod1 and CP49 synergize to control the fiber cell geometry, transparency, and mechanical stiffness of the mouse lens. PLoS One. 2012;7:e48734.

106. Grey AC, Jacobs MD, Gonen T, Kistler J, Donaldson PJ. Insertion of MP20 into lens fibre cell plasma membranes correlates with the formation of an extracellular diffusion barrier. Exp Eye Res. 2003;77:567-74.

107. Shi Y, De Maria AB, Wang H, Mathias RT, FitzGerald PG, Bassnett S. Further analysis of the lens phenotype in Lim2-deficient mice. Invest Ophthalmol Vis Sci. 2011;52:7332-9.

108. Shi Y, Barton K, De Maria A, Petrash JM, Shiels A, Bassnett S. The stratified syncytium of the vertebrate lens. J Cell Sci. 2009;122:1607-15.

109. Yang C, Yang Y, Brennan L, Bouhassira EE, Kantorow M, Cvekl A. Efficient generation of lens progenitor cells and lentoid bodies from human embryonic stem cells in chemically defined conditions. FASEB J. 2010;24:3274-83.

110. Anchan RM, Lachke SA, Gerami-Naini B, Lindsey J, Ng N, Naber C, Nickerson M, Cavallesco R, Rowan S, Eaton JL, et al. Pax6- and Six3-mediated induction of lens cell fate in mouse and human ES cells. PLoS One. 2014;9:e115106.

111. White TW, Gao Y, Li L, Sellitto C, Srinivas M. Optimal lens epithelial cell proliferation is dependent on the connexin isoform providing gap junctional coupling. Invest Ophthalmol Vis Sci. 2007:48:5630-7.

112. Gong X, Baldo GJ, Kumar NM, Gilula NB, Mathias RT. Gap junctional coupling in lenses lacking a3 connexin. Proc Natl Acad Sci U S A. 1998:95:15303-8.

113. Baldo GJ, Gong X, Martinez-Wittinghan FJ, Kumar NM, Gilula NB, Mathias RT. Gap junctional coupling in lenses from a8 connexin knockout mice. J Gen Physiol. 2001;118:447-56.

114. Martinez-Wittinghan FJ, Sellitto C, White TW, Mathias RT, Paul D, Goodenough DA. Lens gap junctional coupling is modulated by connexin identity and the locus of gene expression. Invest Ophthalmol Vis Sci. 2004;45:3629-37.

115. Yu XS, Yin X, Lafer EM, Jiang JX. Developmental regulation of the direct interaction between the intracellular loop of connexin 45.6 and the $C$ terminus of major intrinsic protein (aquaporin-0). J Biol Chem. 2005;280:22081-90.

\section{Submit your next manuscript to BioMed Central and we will help you at every step:}

- We accept pre-submission inquiries

- Our selector tool helps you to find the most relevant journal

- We provide round the clock customer support

- Convenient online submission

- Thorough peer review

- Inclusion in PubMed and all major indexing services

- Maximum visibility for your research

Submit your manuscript at www.biomedcentral.com/submit
) Biomed Central 